\title{
PERANAN ANALISIS LAPORAN KEUANGAN \\ TERHADAP PENGAMBILAN KEPUTUSAN PEMBERIAN KREDIT \\ PADA PT. BPR LPN SUNGAI RUMBAI KABUPATEN DHARMASRAYA
}

\author{
Lidya Martha, SE, MM \\ Dosen Tetap pada STIE"KBP"
}

\begin{abstract}
Abstrak
Dari penelitian yang telah dilakukan diketahui kebijaksanaan perkreditan pada PT. BPR LPN Sungai Rumbai diarahkan kepada peningkatan kredit yang disalurkan dengan menerapkan prinsip kehati-hatian, melaksanakan pelatihan berkesinambungan dan terprogram kepada karyawan bagian kredit, serta kebijaksanaan tingkat suku bunga kredit kompetitif yaitu yang dapat menunjang kemajuan usaha nasabah serta tidak merugikan bank atau saling menguntungkan antara bank dengan debitur. Prosedur penyaluran kredit pada PT. BPR LPN Sungai Rumbai terdiri atas delapan tahap yaitu pengajuan permohonan, wawancara, peninjauan ke lapangan (on the spot), pembuatan appraisal kredit atau penilaian kelayakan penyaluran kredit, komite kredit, persetujuan kredit, perjanjian kredit, dan realisasi kredit. Manajemen perkreditan pada PT. BPR LPN Sungai Rumbai dilakukan dalam bentuk mengetahui dan meneliti tujuan dan maksud kredit bagi calon debitur, analisis kualitatif, analisis kuantitatif, dan analisis yuridis calon debitur. Dalam mengambil keputusan penyaluran kredit kepada calon debiturnya maka PT. BPR LPN Sungai Rumbai melakukan analisis laporan keuangan dari perusahaan calon debitur yang akan dibiayai dari kredit yang meliputi analisa likuditas, solvabilitas, rentabilitas, dan aktivitas serta menentukan kebutuhan modal kerja.
\end{abstract}

\section{Pendahuluan}

\subsection{Latar Belakang Masalah}

Analisis laporan keuangan yang dilakukan oleh perbankan digunakan dalam menilai permohonan kredit baru, sehingga apakah kredit yang dicairkan itu dapat dikembalikan tepat waktunya. Dengan melakukan analisis terhadap asset yang dimiliki perusahaan bertujuan agar kredit yang diberikan tidak mengalami kemacetan. Disamping itu, untuk kredit yang masih berjalan untuk menghindari tunggakan maka dilakukan pengawasan melalui penelitian dan analisis atas laporan keuangan perusahaan. Analisa laporan keuangan merupakan suatu cerminan prestasi manajemen yang menggambarkan posisi keuangan dan hasil-hasil yang telah dicapai oleh suatu perusahaan.

Faktor yang dipertimbangkan dalam pemberian kredit menurut Kuncoro dan Suhardjono $(2002,75)$ adalah : 


\section{Watak (Character)}

Bank seringkali menghadapi gejala kemacetan kredit yang diberikan bukan sebagai akibat tidak adanya prospek usaha yang dibiayai, akan tetapi sebagai tingkahlaku si pemegang kuasa dari perusahaan yang dibiayai tersebut.

2. Kemampuan (Capacity)

Seorang calon debitur yang mengajukan permohonan kredit perlu diketahui oleh bank sejauh mana kemampuannya mengolah usaha yang dipimpinnya.

3. Modal (Capital)

Berapa besarnya modal perusahaan calon debitur, juga merupakan faktor yang patut dinilai oleh bank sebelum kredit diberikan.

4. Jaminan (Collateral)

Sebaiknya bank itu berpikir secara save, artinya setiap pinjaman yang diberikan selalu ada agunan yang dipegang sebagai alternatif terakhir bagi bank untuk menyelesaikan pinjaman yang diberikan.

5. Kondisi Ekonomi (Condition of Economy)

Bank harus mampu membaca kondisi ekonomi dimasa mendatang khususnya atas pengaruh kondisi tersebut terhadap perusahaan yang akan/telah dibiayai.

PT. BPR LPN Sungai Rumbai sebelum memberi kredit akan melakukan analisis terhadap laporan keuangan terhadap calon nasabahnya. Ini dikarenakan dalam aktivitas pemberian kredit, bank akan dihadapkan pada hambatan dan penyimpangan seperti penyalahgunaan kredit, kemacetan dalam pembayaran angsuran dan sebagainya yang akan menimbulkan kerugian pada pihak bank. Masalah-masalah tersebut jika dibiarkan berlarut-larut akan mempengaruhi kelancaran simpanan yang diterimanya dari masyarakat sehingga bank menanggung beban tetap berupa bunga kepada penabung, sedangkan bagi nasabah akan berkurang kesempatan dalam memperoleh kredit.

Dalam pemberian kredit kepada nasabah, bank dituntut untuk lebih cermat dalam menilai segala aspek, baik sisi bank sebagai pemberi kredit, maupun dari sisi nasabah (perusahaan) sebagai penerima kredit. Sebelum memberikan kredit bank harus melihat dulu jenis usaha para nasabah. Apabila setelah melakukan analisis keuangan, Account Officer berkesimpulan bahwa terdapat hal-hal yang kurang beres dalam usaha calon nasabah yang dapat menyebabkan terganggunya kelancaran pembayaran kredit.

Dari laporan keuangan pihak bank akan melakukan analisis laporan keuangan yang biasanya dilakukan selambat-lambatnya 2 minggu, hal ini dilakukan untuk mengetahui bagaimana posisi keuangan perusahaan calon nasabah apakah memang layak untuk diberikan kredit atau tidak. Ada beberapa rasio yang digunakan untuk menganalisis laporan keuangan calon nasabah, diantaranya :

1. Ratio Likuiditas

Ratio Likuiditas yang digunakan di PT. BPR LPN Sungai Rumbai terdiri dari Current Ratio dan Quick Ratio dengan besarnya Current Ratio disyaratkan $\geq 150 \%$ dan Quick Ratio disyaratkan $\geq 85 \%$.

2. Ratio Solvabilitas 
Ratio yang digunakan PT. BPR LPN Sungai Rumbai adalah Total Debt to Total Asset dan Total Debt to Total Equity. Total Debt to Total Asset dan Total Debt to Total Equity yang berlaku di bank BPR adalah $\leq 25 \%$.

3. Ratio Rentabilitas

Ratio yang digunakan PT. BPR LPN Sungai Rumbai adalah Gross Profit Margin, Net Profit Margin, Rate of Return for Invesment, Rate of Return for Equity. Gross Profit Margin yang layak $\geq 20 \%$, karena ini memperlihatkan kemampuan perusahaan dalam menghasilkan laba kotor. Sedangkan untuk Net Profit Margin yang dianggap layak $\geq 10 \%$, karena dengan begitu berarti perusahaan dapat menghasilkan laba bersih $10 \%$ dari setiap transaksinya. Untuk ROI dan ROE yang berlaku dan dianggap layak oleh bank apabila menunjukkan angka $\geq 13 \%$ untuk ROI dan $\geq 15 \%$ untuk ROE.

4. Ratio Aktivitas

Pada Ratio ini pihak PT. BPR LPN Sungai Rumbai tidak menentukan mempunyai persyaratan yang tetap, hanya saja kebijaksanaan bank saja menyesuaikan bagaimana lamanya perputaran modal kerja telah efisien atau sesuai dengan jumlah modal kerja yang telah ada. Tujuannya adalah untuk mengetahui kebutuhan modal kerja dari debitur untuk menjalankan kegiatan usahanya.

\subsection{Perumusan Masalah}

1. Apakah dasar pemberian kredit PT. BPR LPN Sungai Rumbai dari laporan keuangan nasabah?

2. Analisa laporan keuangan yang manakah yang digunakan oleh PT. BPR LPN Sungai Rumbai?

\subsection{Tujuan Penelitian}

Adapun tujuan penulisan dalam penelitian ini adalah sebagai berikut :

1. Untuk mengetahui bagaimana peranan analisis laporan keuangan nasabah terhadap pengambilan keputusan pemberian kredit sehingga dapat dihasilkan keputusan diterima atau tidaknya suatu permohonan kredit

2. Untuk mengetahui analisis yang digunakan PT. BPR LPN Sungai Rumbai Kabupaten Dharmasraya terhadap laporan keuangan nasabahnya.

\section{Tinjauan Literatur}

\subsection{Laporan Keuangan}

Laporan keuangan untuk tujuan umum berdasarkan Standar Akuntansi Keuangan (2002, 1.2) adalah laporan keuangan yang ditujukan untuk memenuhi kebutuhan bersama sebagian besar pengguna laporan keuangan. Laporan keuangan untuk tujuan umum termasuk juga laporan keuangan yang disajikan terpisah atau yang disajikan dalam dokumen publik lainnya seperti laporan tahunan atau prospektus. Pernyataan ini berlaku pula untuk laporan keuangan konsolidasian.

Tujuan laporan keuangan untuk tujuan umum adalah memberikan informasi tentang posisi keuangan, kinerja, dan arus kas perusahaan yang bermanfaat bagi 
sebagian besar kalangan pengguna laporan dalam rangka membuat keputusankeputusan ekonomi serta menunjukkan pertanggungjawaban (stewarship) manajemen atas penggunaan sumber-sumber daya yang dipercayakan kepada mereka. Dalam rangka mencapai tujuan tersebut, suatu laporan keuangan menyajikan informasi mengenai perusahaan yang meliputi :

(a) aktiva;

(b) kewajiban;

(c) ekuitas;

(d) pendapatan dan beban termasuk keuntungan dan kerugian; dan

(e) arus kas.

Laporan keuangan yang lengkap berdasarkan terdiri dari komponenkomponen Standar Akuntansi Keuangan $(2002,1.3)$ berikut ini :

(a) neraca;

(b) laporan laba-rugi;

(c) laporan perubahan ekuitas;

(d) laporan arus kas; dan

(e) catatan atas laporan keuangan.

Adapun pengertian dari neraca dan laporan laba rugi adalah sebagai berikut :

\section{Neraca}

Pengertian neraca menurut Keown $(2002,82)$ adalah gambaran sesaat posisi keuangan perusahaan pada suatu waktu tertentu yang menyajikan kepemilikan aktiva, kewajiban, serta ekuitas pemegang saham dari para pemilik. Aktiva mewakili seluruh sumber daya yang dimiliki perusahaan sementara kewajiban dan ekuitas pemegang saham menunjukkan bagaimana seluruh sumber daya perusahaan didanai.

Neraca menurut Munawir $(2001,13)$ adalah laporan yang sistematis dari suatu perusahaan pada suatu saat tertentu. Jadi tujuan neraca adalah untuk menunjukkan posisi keuangan suatu perusahaan pada suatu tanggal tertentu, biasanya pada waktu dimana buku-buku ditutup dan ditentukan sisanya pada suatu akhir tahun fiskal atau tahun kalender, sehingga neraca sering disebut balance sheet.

Dengan demikian, neraca menurut Munawir $(2001,14)$ terdiri dari tiga bagian utama, yaitu :

a. Aktiva

Dalam pengertian aktiva tidak terbatas pada kekayaan perusahaan yang berwujud saja, tetapi juga termasuk pengeluaran-pengeluaran yang belum dialokasikan (deffeed charges) atau biaya yang masih harus dialokasikan pada penghasilan yang akan datang, serta aktiva yang tidak berwujud lainnya (intangible assets) misalnya goodwill, hak patent, hak penerbitan dan sebagainya.

Pada dasarnya aktiva dapat diklasifikasikan menjadi dua bagian utama yaitu aktiva lancar dan aktiva tidak lancar. Aktiva lancar adalah uang kas dan aktiva lainnya yang dapat diharapkan untuk dicairkan atau ditukarkan menjadi uang tunai, dijual atau dikonsumer dalam periode berikutnya (paling lama satu tahun atau dalam perputaran kegiatan perusahaan yang normal). Yang termasuk 
kelompok aktiva lancar (likuid) adalah kas, investasi jangka pendek, piutang wesel, piutang dagang, persediaan, piutang penghasilan atau penghasilan yang masih harus diterima, dan persekot atau biaya yang dibayar di muka.

Aktiva tidak lancar adalah aktiva yang mempunyai umur kegunaan relatif permanen atau jangka panjang (mempunyai umur ekonomis lebih dari satu tahun atau tidak akan habis dalam satu kali perputaran operasi perusahaan). Yang termasuk aktiva tidak lancar adalah investasi jangka panjang, aktiva tetap, aktiva tetap tidak berwujud, beban yang ditangguhkan, dan aktiva lain-lain.

Yang dimaksud dengan aktiva lain-lain adalah kekayaan atau aktiva perusahaan yang tidak dapat atau belum dapat dimasukkan dalam klasifikasiklasifikasi sebelumnya, misalnya : gedung dalam proses, tanah dalam penyelesaian, pihutang jangka panjang, dan sebagainya.

b. Hutang

Hutang adalah semua kewajiban keuangan perusahaan kepada pihak lain yang belum terpenuhi yang merupakan sumber dana atau modal perusahaan yang berasal dari kreditor. Hutang atau kewajiban perusahaan dibedakan ke dalam hutang lancar (hutang jangka pendek) dan hutang jangka panjang.

Hutang lancar atau hutang jangka pendek adalah kewajiban keuangan perusahaan yang pelunasannya atau pembayaran akan dilakukan dalam jangka pendek (satu tahun sejak tanggal neraca) dengan menggunakan akiva lancar yang dimiliki oleh perusahaan. Hutang lancar meliputi hutang dagang, hutang wesel, hutang pajak, biaya yang masih harus dibayar, hutang jangka panjang yang segera jatuh tempo, dan penghasilan yang diterima di muka.

Hutang jangka panjang adalah kewajiban keuangan yang jangka waktu pembayarannya (jatuh temponya) masih jangka panjang (lebih dari satu tahun sejak tanggal neraca). Hutang jangka panjang meliputi hutang obligasi, hutang hipotik, dan pinjaman jangka panjang yang lain.

c. Modal

Modal merupakan hak atau bagian yang dimiliki oleh pemilik perusahaan yang ditunjukkan dalam pos modal (modal saham), surplus dan laba ditahan. Atau kelebihan nilai aktiva yang dimiliki oleh perusahaan terhadap seluruh hutang-hutangnya.

2. Laporan Laba Rugi

Laporan laba rugi menurut Munawir $(2001,26)$ merupakan suatu laporan yang sistematis tentang penghasilan, biaya, laba rugi yang diperoleh oleh suatu perusahaan selama periode tertentu. Prinsip-prinsip yang umumnya diterapkan dalam laporan laba rugi adalah :

a. Bagian pertama menunjukkan penghasilan yang diperoleh dari usaha pokok perusahaan (penjualan barang dagangan atau memberikan service) diikuti dengan harga pokok dari barang/service yang dijual sehingga diperoleh laba kotor.

b. Bagian kedua menunjukkan biaya-biaya operasional yang terdiri dari biaya penjualan dan biaya umum/administrasi (operating expenses). 
c. Bagian ketiga menunjukkan hasil-hasil yang diperoleh di luar operasi pokok perusahaan, yang diikuti dengan biaya-biaya yang terjadi di luar usaha pokok perusahaan (non operating/financial income dan expenses).

d. Bagian keempat menunjukkan laba atau rugi yang insidentil (extra ordinary gain or loss) sehingga akhirnya diperoleh laba bersih sebelum pajak pendapatan.

\subsection{Likuiditas}

Likuiditas menurut Muslich (2000, 47) menunjukkan tingkat kemudahan relatif suatu aktiva untuk segera dikonversikan ke dalam kas dengan sedikit atau tanpa penurunan nilai; serta tingkat kepastian jumlah kas yang dapat diperoleh.

Untuk memenuhi kemampuan perusahaan dalam memenuhi hutang lancar digunakan pendekatan sebagai berikut :

\section{Current Ratio}

Current ratio ini menurut Munawir $(2001,72)$ menunjukkan tingkat keamanan (margin of safety) kreditor jangka pendek atau kemampuan perusahaan untuk membayar hutang-hutang tersebut.

2. Quick (Acid Test) Ratio

Quick ratio atau acid test ratio menurut Munawir (2001, 74) merupakan perbandingan antara aktiva lancar dikurangi persediaan dengan hutang lancar.

\subsection{Solvabilitas}

Rasio solvabilitas menurut Husnan (2001, 219) mengukur seberapa banyak dana yang disupply oleh pemilik perusahaan dalam proporsinya dengan dana yang diperoleh dari kreditur perusahaan.

Rasio-rasio solvabilitas yang dapat digunakan menurut Munawir $(2001,82)$ adalah :

\section{Total Debt to Total Assets}

Merupakan bahagian kecil dari aktiva yang digunakan untuk menjamin seluruh hutang atau perbandingan dengan hutang yang ada dibandingkan dengan jumlah aktiva keseluruhan. Yang termasuk hutang adalah kewajiban lancar dan semua hutang jangka panjang.

\section{Total Debt to Equity Ratio}

Merupakan bagian kecil dari pasiva yang digunakan untuk menjamin seluruh hutang atau perbandingan dengan hutang yang ada dibandingkan dengan jumlah modal keseluruhan. Artinya, ratio ini menunjukkan seberapa jauh modal sendiri mampu menutupi hutang pada saat perusahaan dilikuidasi.

\subsection{Rentabilitas}

Rasio rentabilitas atau profitabilitas menurut Weston dan Copeland (2000, 232) merupakan hasil akhir dari berbagai kebijakan dan keputusan. Rasio profitabilitas ini akan memberikan jawaban akhir tentang efektivitas manajemen.

Pendekatan lebih lanjut untuk mengetahui rasio profitabilitas adalah dengan menggunakan konsep sebagai berikut :

1. Gross Profit Margin

Gross profit margin menurut Sartono $(2000,24)$ adalah perbandingan antara laba kotor dengan tingkat penjualan yang dicapai oleh perusahaan pada periode yang 
sama. Ratio ini mencerminkan laba kotor yang dapat dicapai setiap rupiah penjualan yang terjadi.

2. Nett Profit Margin

Nett profit margin menurut Sutojo $(2000,56)$ merupakan perbandingan antara laba bersih dengan penjualan. Artinya, berapa persen keuntungan bersih yang diperoleh oleh perusahaan selama periode tertentu (tahun buku) dari setiap rupiah penjualan.

\section{Return On Investment}

Return on investment menurut Sutojo (2000, 57) memberikan gambaran tentang kemampuan perusahaan mengoperasikan harta untuk mencari keuntungan. Rasio ini sekaligus menggambarkan efisiensi kerja perusahaan yang bersangkutan. Return on assets merupakan perbandingan antara laba bersih dengan total aktiva dengan tujuan untuk mengukur tingkat pengembalian investasi total atau return on investment.

4. Return On Equity

Return on equity menurut Sutojo (2000, 57) diperoleh dengan jalan memperbandingkan jumlah keuntungan yang diperoleh bank selama masa tertentu dengan jumlah harta neto pemegang saham (modal disetor, laba ditahan, laba/rugi berjalan).

2.5. Aktivitas

Rasio aktivitas menurut Riyanto (2000, 331) merupakan rasio-rasio yang dimaksudkan untuk mengukur sampai seberapa jauh efektivitas perusahaan dalam mengerjakan sumber-sumber dananya.

Pendekatan lebih lanjut untuk mengetahui rasio aktivitas adalah dengan menggunakan konsep seperti dikemukakan Riyanto $(2000,334)$ sebagai berikut :

1. Receivable Turnover

Receivable turnover memberikan gambaran kemampuan dana yang tertanam dalam piutang berputar dalam suatu periode tertentu. 2. Inventory Turnover

Inventory Turnover memberikan gambaran kemampuan dana yang tertanam dalam persediaan berputar dalam suatu periode tertentu.

3. Working Capital Turnover

Working capital turnover memberikan gambaran kemampuan modal kerja (netto) berputar dalam suatu periode perputaran kas dari perusahaan.

\subsection{Pengertian Kredit}

Rivai dan Veithzal (2006, 3) mengemukakan istilah kredit berasal dari perkataan latin credo, yang berarti I believe, I trust (saya percaya, atau saya menaruh kepercayaan). Perkataan credo berasal dari perkataan sansekerta cred yang berarti kepercayaan (trust) dan perkataan latin do yang berarti saya menaruh. Sesudah kombinasi tersebut menjadi bahasa latin, kata kerjanya dan kata bendanya masingmasing menjadi credere dan creditum. Kata credere merupakan pasangan kredit merupakan utang (debt). Berdasarkan hal tersebut maka dikemukakan pengertian kredit adalah penyerahan barang, jasa, atau uang dari satu pihak (kreditor atau pemberi jaminan) atas dasar kepercayaan kepada pihak lain (nasabah atau pengutang/borrower) dengan janji membayar dari penerima kredit kepada pemberi kredit pada tanggal yang telah disepakati kedua belah pihak. 
Pengertian kredit berdasarkan Undang-Undang Perbankan No. 10 Tahun 1998 $(2002,10)$ adalah penyediaan uang atau tagihan yang dapat dipersamakan dengan itu berdasarkan persetujuan atau kesepakatan pinjam-meminjam antara bank dengan pihak lain yang mewajibkan pihak peminjam untuk melunasi hutangnya setelah jangka waktu tertentu dengan pemberian bunga.

III. Metode Penelitian

3.1. Tempat Penelitian

Penelitian ini dilakukan pada PT. BPR LPN SUNGAI RUMBAI KABUPATEN DHARMASRAYA.

\subsection{Teknik Analisa data}

Dalam penulisan ini, untuk memperoleh data yang dibutuhkan sesuai dengan topik maka metode-metode yang digunakan sebagai berikut :

1. Analisis Kualitatif

Yaitu untuk mengetahui analisis laporan keuangan terhadap pengambilan keputusan pemberian kredit pada PT. BPR LPN Sungai Rumbai.

2. Analisis Kuantitatif

Yaitu dengan menggunakan rumus sebagai berikut :

a. Rasio Likuiditas

Yaitu rasio untuk mengetahui kemampuan perusahaan dalam membiayai operasi dan memenuhi kewajiban finansial pada saat ditagih, dengan menggunakan rasio sebagai berikut :

1) Current Ratio

$$
\text { Current Ratio }=\frac{\text { Aktiva Lancar }}{\text { Hutang Lancar }} \times 100 \%
$$

\section{2) Quick Ratio}

$$
\text { Quick Ratio }=\frac{\text { Kas }+ \text { Surat-Surat Berharga }+ \text { Piutang }}{\text { Hutang Lancar }} \times 100 \%
$$

b. Rasio Solvabilitas

Yaitu kemampuan perusahaan dalam menilai seberapa besar porsi hutang dalam membelanjai aktiva perusahaan, dengan menggunakan rasio sebagai berikut :

1) Total Debt to Total Assets

$$
\text { Total Debt to Total Assets }=\frac{\text { Total Kewajiban }}{\text { Total Aktiva }} \times 100 \%
$$

\section{2) Total Debt to Equity Ratio}

$$
\text { Total Debt to Equity Ratio }=\frac{\text { Total Kewajiban }}{\text { Total Modal Sendiri }} \times 100 \%
$$

c. Rasio Rentabilitas/Profitabilitas 
Yaitu rasio yang dapat digunakan untuk meniali kemampuan perusahaan untuk memperoleh keuntungan, dengan menggunakan rasio sebagai berikut :

1) Gross Profit Margin

$$
\text { Gross Profit Margin }=\frac{\text { Laba Kotor }}{\text { Penjualan }} \times 100 \%
$$

2) Nett Profit Margin

3) Return On Investment

$$
\text { Nett Profit Margin }=\frac{\text { Laba Bersih }}{\text { Penjualan }} \times 100 \%
$$

$$
\text { Return On Investment }=\frac{\text { Laba Bersih }}{\text { Total Aktiva }} \times 100 \%
$$

4) Return On Equity

$$
\text { Return On Equity }=\frac{\text { Laba Bersih }}{\text { Modal Sendiri }} \times 100 \%
$$

c. Rasio Aktivitas

Yaitu Rasio untuk kemampuan perusahaan dalam melaksanakan aktivitas sehari-hari atau kemampuan perusahaan dalam penjualan, penagihan piutang maupun pemanfaatan aktiva, dengan menggunakan rasio sebagai berikut :

1) Receivable Turnover

$$
\text { Receivable Turnover }=\frac{\text { Piutang }}{\text { Penjualan }} \times 365 \text { hari }
$$

2) Inventory Turnover

$$
\text { Inventory Turnover }=\frac{\text { Persediaan }}{\text { HPP }} \times 365 \text { hari }
$$

3) Working Capital Turnover

$$
\text { Working Capital Turnover }=\frac{\text { Penjualan Netto }}{\text { Aktiva Lancar }- \text { Hutang Lancar }}
$$

IV. Hasil Penelitian dan Pembahasan

\subsection{Kebijaksanaan Perkreditan}

Untuk melaksanakan fungsi dalam menyalurkan kredit kepada masyarakat maka PT. BPR LPN Sungai Rumbai menetapkan kebijaksanaan-kebijaksanaan yang dilakukan dalam bidang perkreditan. Kebijaksanaan-kebijaksanaan tersebut antara lain :

1. Mengembangkan dan meningkatkan kredit yang disalurkan dengan cara memperbanyak jumlah debitur untuk memperkecil resiko yang ditimbulkan dalam penyaluran kredit. 
2. Dalam melaksanakan ekspansi kredit tetap konsisten pada prinsip kehati-hatian (prudential banking) dan kelayakan usaha sehingga ekspansi kredit dapat berjalan secara sehat, terarah, dan terencana.

3. Mengupayakan pelaksanaan pelatihan secara berkesinambungan dan terprogram, khususnya petugas-petugas yang berkaitan dengan pengelolaan kredit. Hal ini sangat perlu dilakukan karena mutu seorang petugas kredit sangat mempengaruhi dan menentukan sekali terhadap kesehatan penyaluran kredit pada masa yang akan datang. Seorang petugas kredit tidak hanya bertugas sebagai pemrakarsa kredit belaka, akan tetapi lebih dari itu juga ikut bertanggungjawab atas keberhasilan usaha nasabah, dalam arti ikut bertanggungjawab dalam membina debitur.

4. Kebijaksanaan suku bunga kredit yang berorientasi pasar, dalam arti suku bunga tersebut benar-benar kompetitif dan dapat menunjang kemajuan usaha nasabah serta tidak merugikan bank atau saling menguntungkan antara bank dengan debitur.

\subsection{Prosedur Penyaluran Kredit}

Prosedur-prosedur penyaluran kredit yang harus dilalui calon debitur PT. BPR LPN Sungai Rumbai adalah :

1. Pengajuan permohonan

Pengajuan permohonan kredit oleh calon debitur dengan plafond yang dibutuhkan dengan melampirkan :

a. Foto kopi KTP.

b. Foto kopi Kartu Keluarga

c. Pas foto 4x6 sebanyak 2 lembar.

d. Izin usaha, dalam bentuk SIUP, SITU, TDP dan NPWP, serta Surat Keterangan Usaha dan Domisili.

e. Laporan keuangan selama 3 tahun terakhir bagi calon debitur yang mengajukan kredit untuk kegiatan usaha.

f. Foto kopi agunan yang diserahkan yaitu sertifikat, BPKB, atau deposito.

2. Proses wawancara

Pada saat calon debitur datang mengantarkan permohonan, Bagian Kredit melakukan wawancara singkat tentang usaha yang dijalankan dan jaminan yang diserahkannya. Untuk memperkuat hasil wawancara dilakukan kunjungan ke lokasi usaha dan jaminan dari calon debitur (on the spot) oleh Account Officer Kredit.

3. Peninjauan ke lapangan (on the spot)

Peninjauan ke lapangan dilakukan Account Officer Kredit untuk melihat objek usaha nasabah termasuk barang jaminan secara langsung guna mengumpulkan keterangan (data-data usaha calon debitur).

4. Pembuatan appraisal kredit atau penilaian kelayakan penyaluran kredit

Berdasarkan peninjauan ke lapangan, maka Bagian Kredit melakukan penilaian kelayakan penyaluran kredit dengan menggunakan pendekatan $5 \mathrm{C}, 7 \mathrm{P}$, dan 3R.

5. Komite Kredit 
Berdasarkan analisis kredit yang dibuat, maka Bagian Kredit mengajukannya ke Komite Kredit. Selanjutnya Komite Kredit memberikan tanggapan atas permohonan kredit yang diajukan calon debitur.

6. Persetujuan kredit

Persetujuan kredit merupakan penentuan dari Direktur Utama dari suatu permohonan yang didasarkan atas hasil rapat komite kredit. Jika permintaan kredit ditolak maka dibuat surat pemberitahuan kepada pemohon bahwa permintaan kredit ini tidak dapat disetujui tetapi jika permintaan kredit disetujui maka pihak bank akan membuat surat permberitahuan persetujuan kredit yang memuat jenis fasilitas kredit yang disetujui beserta uraian jaminan.

7. Perjanjian kredit

Perjanjian kredit dilakukan setelah calon debitur menyetujui ketentuan yang tercantum dalam Surat Pemberitahuan Persetujuan kredit, antara lain maksimum/limit fasilitas waktu, jangka waktu berlakunya kredit, bentuk jaminan, tujuan penggunaan kredit, suku bunga, bea materai serta sanksi-sanksi seperti terlambatnya bunga dan pembayaran angsuran kredit.

8. Realisasi kredit

Kredit dapat ditarik sesuai dengan cara-cara yang ditentukan bank, antara lain membuat kuitansi dan dokumen lainnya yang dapat diterima sebagai perintah pembayaran atau dengan pemindahbukuan atas beban rekening pinjaman nasabah.

\subsection{Analisis Penyaluran Kredit}

Analisis dalam penyaluran kredit yang diterapkan PT. BPR LPN Sungai Rumbai kepada calon debiturnya yaitu :

1. Tujuan dan maksud kredit bagi calon debitur.

2. Analisis kualitatif, meliputi :

a. Latar belakang calon debitur.

b. Latar belakang usaha dan prospek usaha.

c. Manajemen permodalan.

d. Aspek teknis dan aspek produksi.

e. Pemasaran dan biaya produksi.

f. Hubungan dengan perbankan.

g. $5 \mathrm{C}, 7 \mathrm{P}$, dan $3 \mathrm{R}$ yang terdiri dari :

1) $5 \mathrm{C}$ yaitu :

a) Character (watak) dilakukan dengan mengadakan wawancara untuk mengetahui watak calon debitur sehingga dapat diketahui daftar riwayat hidup calon debitur.

b) Capacity (kemampuan) dilakukan dengan menganalisis kemampuan calon debitur menjalankan perusahaan dengan baik dan benar dengan cara melihat perkembangan usaha debitur melalui laporan keuangan dari calon debitur dan bila calon debitur tidak ada laporan keuangannya maka petugas bank yaitu bagian account officer yang membuatnya.

c) Capital (modal) dilakukan dengan menganalisis struktur modal calon debitur dengan cara menanyakan kepada calon debitur sumber modal untuk menjalankan usaha selama ini. 
d) Condition of economic (kondisi perekonomian) dilakukan dengan menganalisis kondisi perekonomian yang dapat mempengaruhi usaha calon debitur.

e) Collateral (agunan) dilakukan dengan menganalisis secara yuridis dan ekonomis terhadap agunan calon debitur.

2) 7 P yaitu :

a) Personality (kepribadian) dilakukan dengan meneliti sifat dan perilaku calon debitur.

b) Party (pengklasifikasian nasabah) dilakukan dengan mengelompokkan calon debitur ke dalam klasifikasi yang tertentu berdasarkan modal, karakter dan loyalitasnya.

c) Purpose (tujuan) dilakukan dengan meneliti tujuan penggunaan kredit oleh calon debitur yaitu digunakan untuk usaha atau untuk konsumsi.

d) Prospect (prospek usaha nasabah) dilakukan dengan meneliti prospek dari usaha yang dijalankan calon debitur.

e) Payment (pembayaran) dilakukan dengan meneliti cara pembayaran kembali kredit yang disalurkan dengan memperhitungkan kelancaran usaha calon debitur dengan menggunakan pendekatan laporan keuangan dari calon debitur atau laporan keuangan yang dibuat oleh account officer bila calon debitur tidak tersedia laporan keuangannya.

f) Profitability (kemampulabaan) dilakukan dengan meneliti kemampuan nasabah mendapatkan laba.

g) Protection (perlindungan) dilakukan dengan meneliti bentuk jaminan yang diberikan calon debitur.

3) 3R yaitu :

a) Returns dilakukan dengan memperhitungkan hasil yang dicapai calon debitur setelah memperoleh kredit. Hal ini dilakukan dengan cara melihat kemungkinan besarnya laba yang dihasilkan calon debitur dengan memperhitungkan besarnya penjualan dan biaya-biaya yang dikeluarkan untuk menjalankan usaha.

b) Repayment dilakukan dengan memperhitungkan kemampuan, jadwal dan jangka waktu pembayaran kredit oleh calon debitur.

c) Risk bearing ability dilakukan dengan memperhitungkan besarnya kemampuan calon debitur dalam menghadapi resiko-resiko yang mungkin terjadi.

3. Analisis kuantitatif, dalam bentuk :

a. Neraca dan Laporan Laba/Rugi

b. Perhitungan kebutuhan modal kerja

c. Analisis keuangan, yang meliputi :

1) Likuiditas, dengan cara meneliti current ratio dan quick ratio calon debitur dengan besarnya Current Ratio disyaratkan $\geq 150 \%$ dan Quick Ratio $\geq 85 \%$.

2) Solvabilitas, dengan cara meneliti Total Debt to Total Asset dan Total Debt to Total Equity. Total Debt to Total Assets dan Total Debt to Total Equity 
yang berlaku $\leq 25 \%$, karena hal ini menggambarkan bahwa $25 \%$ harta yang dimiliki berasal dari pinjaman.

3) Rentabilitas, dengan cara meneliti Gross Profit Margin, Net Profit Margin, Rate of Return for Invesment, Rate of Return for Equity. Gross Profit Margin yang layak adalah $\geq 20 \%$, karena ini memperlihatkan kemampuan perusahaan dalam menghasilkan laba kotor. Sedangkan untuk Net Profit Margin yang dianggap layak $\geq 10 \%$, karena dengan begitu berarti perusahaan dapat menghasilkan laba bersih $10 \%$ dari setiap transaksinya. Untuk ROI dan ROE yang berlaku dan dianggap layak oleh bank apabila menunjukkan angka $\geq 13 \%$ untuk ROI dan $\geq 15 \%$ untuk ROE.

4) Aktivitas, yang bertujuan untuk mengetahui kebutuhan modal kerja dalam calon debitur.

4. Analisis yuridis, dengan melakukan penilaian terhadap :

a. Jenis jaminan.

b. Nilai dan rasio jaminan.

c. Pengikatan jaminan.

4.4. Peranan Analisis Laporan Keuangan Terhadap Pengambilan Keputusan Pemberian Kredit

Penggunaan dan penerapan metode analisis laporan keuangan dapat dilihat dalam pembahasan ini dengan memberikan gambaran dalam sebuah kasus guna memperjelas mengenai analisis laporan keuangan nasabah pada PT. BPR LPN Sungai Rumbai dalam kaitannya dengan keputusan pemberian kredit yaitu berupa kredit modal kerja. Contoh analisis laporan keuangan berikut ini merupakan perusahaan yang nama permohonan kreditnya telah diterima PT. BPR LPN Sungai Rumbai. Perusahaan (PT. X) ini bergerak dalam bidang perdagangan yang cukup maju di daerah Sungai Rumbai. PT. X ini mengajukan kredit modal kerja guna meningkatkan usahanya dalam bidang perdagangan. Dari laporan keuangan yang diserahkan kepada bank , PT. BPR LPN Sungai Rumbai melakukan analisa terhadap laporan keuangan calon debitur yang biasanya dilakukan selambat-lambatnya 2 minggu dengan tujuan untuk mengetahui posisi keuangan perusahaan calon debitur dan dapat menentukan calon debitur layak atau tidak layak untuk diberikan kredit.

\subsubsection{Aspek Likuiditas}

Likuiditas menunjukkan kemampuan perusahaan untuk memenuhi kewajiban jangka pendeknya. Dalam penilaian likuiditas digunakan analisa Current Ratio CR) dan Quick Ratio (QR) seperti yang dikemukakan pada tabel 3.1.

Tabel 1.

Rasio Likuditas PT. X

Untuk Tahun 2003, 2004, dan 2005

(Dalam Ribuan Rupiah)

\begin{tabular}{|c|l|c|c|c|}
\hline No. & Keterangan & 31-12-2003 & 31-12-2004 & 31-12-2005 \\
\hline \hline 1 & Aktiva Lancar & 98.662 & 103.803 & 83.721 \\
2 & Kas & 32.532 & 37.778 & 25.446 \\
3 & Piutang & 32.230 & 31.100 & 31.225
\end{tabular}




\begin{tabular}{|c|l|c|c|c|}
4 & Hutang Lancar & 61.427 & 57.769 & 45.714 \\
\hline \hline 5 & CR $(1: 4)$ & $161 \%$ & $180 \%$ & $183 \%$ \\
6 & QR $([2+3]: 4)$ & $105 \%$ & $119 \%$ & $124 \%$ \\
\hline
\end{tabular}

Dari tabel 1. dapat disimpulkan bahwa perusahan mempunyai kemampuan untuk memenuhi kewajiban jangka pendeknya yang dapat dilihat dari terjadinya peningkatan Current Ratio dan Quick Ratio dari tahun 2003 sampai dengan tahun 2005. Current Ratio mengalami peningkatan dari $161 \%$ pada tahun 2003 menjadi $180 \%$ pada tahun 2004 dan $183 \%$ pada tahun 2005. Secara rata-rata Current Ratio PT. X dari tahun 2003 sampai dengan tahun 2005 adalah $174 \%$ berarti setiap hutang lancar Rp. 100,- dijamin oleh aktiva lancar Rp. 174. Quick Ratio mengalami peningkatan dari $105 \%$ pada tahun 2003 menjadi 119\% pada tahun 2004 dan $124 \%$ pada tahun 2005. Secara rata-rata Quick Ratio PT. X dari tahun 2003 sampai dengan tahun 2005 adalah 116\% berarti setiap hutang lancar Rp. 100,- dijamin oleh aktiva lancar yang lebih likuid (quick assets) Rp. 116. Dari rasio likuditas tersebut maka dinilai PT. X memenuhi persyaratan likuditas karena Current Ratio lebih dari $150 \%$ dan Quick Ratio lebih dari $85 \%$.

4.4.2. Aspek Solvabilitas

Solvabilitas menunjukkan kemampuan perusahaan untuk melunasi kewajibannya. Dalam penilaian solvabilitas digunakan analisa Total Debt to Total Asset (TDTA) dan Total Debt to Total Equity (TDTE) seperti yang dikemukakan pada tabel 2.

Tabel 2.

Rasio Solvabilitas PT. X

Untuk Tahun 2003, 2004, dan 2005

(Dalam Ribuan Rupiah)

\begin{tabular}{|c|l|c|c|c|}
\hline No. & Keterangan & $\mathbf{3 1 - 1 2 - 2 0 0 3}$ & $\mathbf{3 1 - 1 2 - 2 0 0 4}$ & $\mathbf{3 1 - 1 2 - 2 0 0 5}$ \\
\hline \hline 1 & Total Kewajiban & 80.177 & 70.269 & 50.918 \\
2 & Total Aktiva & 573.683 & 615.291 & 738.803 \\
3 & Total Modal Sendiri & 493.506 & 545.022 & 687.885 \\
\hline \hline 4 & TDTA $(1: 2)$ & $14 \%$ & $11 \%$ & $7 \%$ \\
5 & TDTE $(1: 3)$ & $16 \%$ & $13 \%$ & $7 \%$ \\
\hline
\end{tabular}

Dari tabel.2. dapat disimpulkan bahwa perusahan mempunyai kemampuan untuk memenuhi kewajibannya yang dapat dilihat dari terjadinya penurunan Total Debt to Total Asset dan Total Debt to Total Equity dari tahun 2003 sampai dengan tahun 2005. Total Debt to Total Asset mengalami penurunan dari 14\% pada tahun 2003 menjadi 11\% pada tahun 2004 dan 7\% pada tahun 2005. Secara rata-rata Total Debt to Total Asset PT. X dari tahun 2003 sampai dengan tahun 2005 adalah $11 \%$ berarti setiap Rp. 100,- aktiva menjamin hutang Rp. 11. Total Debt to Total Equity mengalami penurunan dari $16 \%$ pada tahun 2003 menjadi 13\% pada tahun 2004 dan 7\% pada tahun 2005. Secara ratarata Total Debt to Total Equity PT. X dari tahun 2003 sampai dengan tahun 2005 adalah $12 \%$ berarti setiap Rp. 100,- modal yang dimiliki menjamin hutang Rp. 12. Dari rasio solvabilitas tersebut maka dinilai PT. X memenuhi persyaratan solvabilitas karena Total Debt to Total Asset dan Total Debt to Total Equity dari PT. X kecil dari 25\% 4.4.3. Aspek Rentabilitas 
Rentabilitas menunjukkan kemampuan perusahaan dalam menghasilkan laba selama satu periode tertentu. Dalam penilaian solvabilitas digunakan analisa Gross Profit Margin, Net Profit Margin, Return On Invesment, Return On Equity seperti yang dikemukakan pada tabel 3.

Tabel 3.

Rasio Rentabilitas PT. X

Untuk Tahun 2003, 2004, dan 2005

(Dalam Ribuan Rupiah)

\begin{tabular}{|c|l|c|r|r|}
\hline No. & Keterangan & $\mathbf{2 0 0 3}$ & $\mathbf{2 0 0 4}$ & \multicolumn{1}{|c|}{$\mathbf{2 0 0 5}$} \\
\hline \hline 1 & Penjualan & 845.750 & 1.019 .688 & 1.160 .863 \\
2 & Laba Kotor & 178.278 & 237.848 & 301.851 \\
3 & Laba Bersih & 87.030 & 122.103 & 165.881 \\
4 & Total Aktiva & 573.683 & 615.291 & 738.803 \\
5 & Modal Sendiri & 493.506 & 545.022 & 687.885 \\
\hline \hline 6 & GPM (2:1) & $21 \%$ & $23 \%$ & $26 \%$ \\
7 & NPM (3:1) & $10 \%$ & $12 \%$ & $14 \%$ \\
8 & ROI (3:4) & $15 \%$ & $20 \%$ & $22 \%$ \\
9 & ROE (3:5) & $18 \%$ & $22 \%$ & $24 \%$ \\
\hline
\end{tabular}

Dari tabel 3. dapat disimpulkan bahwa perusahan mengalami peningkatan dalam menghasilkan laba dapat dilihat dari terjadinya peningkatan Gross Profit Margin, Net Profit Margin, Return On Invesment, Return On Equity dari tahun 2003 sampai dengan tahun 2005. Gross Profit Margin mengalami peningkatan dari 21\% pada tahun 2003 menjadi 23\% pada tahun 2004 dan 26\% pada tahun 2005. Secara rata-rata Gross Profit Margin PT. X dari tahun 2003 sampai dengan tahun 2005 adalah 23\% berarti berarti setiap Rp. 100,- penjualan menghasilkan laba kotor Rp. 23. Net Profit Margin mengalami peningkatan dari 10\% pada tahun 2003 menjadi $12 \%$ pada tahun 2004 dan $14 \%$ pada tahun 2005. Secara rata-rata Net Profit Margin PT. X dari tahun 2003 sampai dengan tahun 2005 adalah $12 \%$ berarti berarti setiap Rp. 100,- penjualan menghasilkan laba bersih Rp. 12. Return On Invesment mengalami peningkatan dari $15 \%$ pada tahun 2003 menjadi $20 \%$ pada tahun 2004 dan 22\% pada tahun 2005. Secara rata-rata Return On Invesment PT. X dari tahun 2003 sampai dengan tahun 2005 adalah 19\% berarti berarti setiap Rp. 100,- aktiva menghasilkan laba bersih Rp. 19. Return On Equity mengalami peningkatan dari 18\% pada tahun 2003 menjadi 22\% pada tahun 2004 dan 24\% pada tahun 2005. Secara rata-rata Return On Equity PT. X dari tahun 2003 sampai dengan tahun 2005 adalah $21 \%$ berarti berarti setiap Rp. 100,- modal menghasilkan laba bersih Rp. 21. Dari rasio rentabilitas tersebut maka dinilai PT. X memenuhi persyaratan rentabilitas karena Gross Profit Margin lebih dari 20\%, Net Profit Margin lebih dari $10 \%$, ROI lebih dari $13 \%$ dan ROE lebih dari $15 \%$.

4.4.4. Aspek Aktivitas

Aktivitas menunjukkan efektifitas perusahaan mempergunakan sumber-sumber yang ada dalam pengendaliannya selama satu periode tertentu. Dalam penilaian aktivitas digunakan analisa Receivable Turnover (RTO), Inventory Turnover (ITO), dan Working Capital Turnover (WCTO) seperti yang dikemukakan pada tabel 4. 
Rasio Aktivitas PT. X

Untuk Tahun 2003, 2004, dan 2005

(Dalam Ribuan Rupiah)

\begin{tabular}{|c|l|r|r|r|}
\hline No. & \multicolumn{1}{|c|}{ Keterangan } & 31-12-2003 & 31-12-2004 & 31-12-2005 \\
\hline \hline 1 & Piutang & 32.230 & 31.100 & 31.225 \\
2 & Persediaan & 33.900 & 34.925 & 27.050 \\
3 & Aktiva Lancar & 98.662 & 103.803 & 83.721 \\
4 & Hutang Lancar & 61.427 & 57.769 & 45.714 \\
5 & Penjualan & 845.750 & 1.019 .688 & 1.160 .863 \\
6 & HPP & 667.472 & 781.840 & 859.012 \\
\hline \hline 8 & RTO ( [ 1:5 ] x 365 Hari) & 14 Hari & 11 Hari & 10 Hari \\
9 & ITO ( [ 2: 6 ] x 365 Hari) & 19 Hari & 16 Hari & 11 Hari \\
10 & WCTO ( 8 +9) & 33 Hari & 27 Hari & 21 Hari \\
\hline
\end{tabular}

Dari tabel 4. dapat disimpulkan bahwa perusahan mengalami peningkatan aktivitas yang dapat dilihat dari terjadinya penurunan Receivable Turnover dan Inventory Turnover, dan Working Capital Turnover mengalami penurunan dari tahun 2003 sampai dengan tahun 2005. Receivable Turnover mengalami penurunan dari 14 Hari pada tahun 2003 menjadi 11 hari pada tahun 2004 dan 10 hari pada tahun 2005 . Secara rata-rata Receivable Turnover PT. X dari tahun 2003 sampai dengan tahun 2005 adalah 12 hari berarti rata-rata dana yang tertanam dalam piutang 12 hari. Inventory Turnover mengalami penurunan dari 19 hari pada tahun 2003 menjadi 16 hari pada tahun 2004 dan 11 hari pada tahun 2005. Secara rata-rata Inventory Turnover PT. X dari tahun 2003 sampai dengan tahun 2005 adalah 15 hari berarti rata-rata dana yang tertanam dalam persediaan 15 hari. Working Capital Turnover mengalami penurunan dari 33 Hari pada tahun 2003 menjadi 27 Hari pada tahun 2004 dan 21 kali pada tahun 2005. Secara rata-rata Working Capital Turnover PT. X dari tahun 2003 sampai dengan tahun 2005 adalah 21 hari berarti rata-rata dana yang tertanam dalam modal kerja 21 hari dalam setahunnya.

Setelah melakukan analisis rasio aktivitas calon debiturnya, selanjutnya PT. BPR LPN Sungai Rumbai akan menentukan besarnya kredit yang akan diberikan dengan langkah-langkah sebagai berikut :

1. Menentukan Perputaran Modal Kerja

$$
\begin{aligned}
\text { ITO }=\frac{\text { Persediaan }}{\text { HPP }} \times 365 \text { Hari }=\frac{27.050 .000}{859.012 .000} \times 365 \text { Hari } & =11 \text { Hari } \\
\text { RTO }=\frac{\text { Piutang }}{\text { Penjualan }} \times 365 \text { Hari }=\frac{31.225 .000}{1.160 .863 .000} \times 365 \text { Hari } & =\underline{10 \text { Hari }}+ \\
\text { WCTO } & =21 \text { Hari }
\end{aligned}
$$

\section{OPE (Out of Pocket Expense)}

$\mathrm{OPE}=\mathrm{HPP}+$ Biaya Penjualan dan Administrasi

$\mathrm{OPE}=859.012 .000+56.768 .000$

$\mathrm{OPE}=915.780 .000$ 


\section{NWC (Net Working Capital)}

$$
\begin{aligned}
& \text { NWC }=\text { Aktiva Lancar }- \text { Hutang Lancar } \\
& \text { NWC }=83.721 .000-45.714 .000 \\
& \text { NWC }=38.007 .000
\end{aligned}
$$

4. Proyeksi Penjualan Tahun $2006=20 \%(120 \%)$

$$
\begin{aligned}
\text { Kebutuhan Modal Kerja } & =\frac{\text { WCTO }}{365} \times 120 \% \text { x OPE } \\
& =\frac{21}{365} \times 120 \% \times 915.780 .000 \quad=63.226 .000 \\
\text { Hutang Dagang } & =\frac{10.994 .000}{52.232 .000}- \\
\text { NWC } & =\underline{38.007 .000}- \\
\text { Kebutuhan Modal Kerja } & =14.225 .000
\end{aligned}
$$

Jadi PT. X dapat memperoleh kredit sebesar Rp. 14.225.000,- dengan agunan yang telah disetujui dalam perjanjian kredit oleh nasabah dengan pihak PT. BPR LPN Sungai Rumbai.

\section{Kesimpulan}

Kebijaksanaan perkreditan pada PT. BPR LPN Sungai Rumbai diarahkan kepada peningkatan kredit yang disalurkan dengan menerapkan prinsip kehati-hatian, melaksanakan pelatihan berkesinambungan dan terprogram kepada karyawan bagian kredit, serta kebijaksanaan tingkat suku bunga kredit kompetitif yaitu yang dapat menunjang kemajuan usaha nasabah serta tidak merugikan bank atau saling menguntungkan antara bank dengan debitur.

Prosedur penyaluran kredit pada PT. BPR LPN Sungai Rumbai terdiri atas delapan tahap yaitu pengajuan permohonan, wawancara, peninjauan ke lapangan (on the spot), pembuatan appraisal kredit atau penilaian kelayakan penyaluran kredit, komite kredit, persetujuan kredit, perjanjian kredit, dan realisasi kredit.

Manajemen perkreditan pada PT. BPR LPN Sungai Rumbai dilakukan dalam bentuk mengetahui dan meneliti tujuan dan maksud kredit bagi calon debitur, analisis kualitatif, analisis kuantitatif, dan analisis yuridis calon debitur.

Dalam mengambil keputusan penyaluran kredit kepada calon debiturnya maka PT. BPR LPN Sungai Rumbai melakukan analisis laporan keuangan dari perusahaan calon debitur yang akan dibiayai dari kredit yang meliputi analisa likuditas, solvabilitas, rentabilitas, dan aktivitas serta menentukan kebutuhan modal kerja. 


\section{DAFTAR PUSTAKA}

Flippo, Edwin B. 2001. Manajemen Personalia. Jakarta : Erlangga.

Handoko, T. Hani. 2001. Teori dan Perilaku Organisasi Perusahaan, Yogyakarta : BPFE.

Husnan, Suad. 2001. Manajemen Keuangan, Teori dan Penerapan. Yogyakarta : BPFE.

Ikatan Akuntansi Indonesia. 2002. Standar Akuntansi Keuangan. Jakarta : Salemba Empat.

Keown, Arthur J. 2002. Dasar-Dasar Manajemen Keuangan. Jakarta : Salemba Empat.

Kuncoro, Mudrajad dan Suhardjono. 2002. Manajemen Perbankan. Yogyakarta : BPFE.

Munawir, S. 2001. Analisa Laporan Keuangan. Yogyakarta : Liberty.

Muslich, Mohamad. 2000. Manajemen Keuangan Modern, Perencanaan dan Kebijaksanaan. Jakarta : Bumi Aksara.

Riyanto, Bambang. 2000. Dasar-Dasar Pembelanjaan Perusahaan. Yogyakarta : Gajah Mada.

Rivai, Veithzal dan Veithzal, Andria Permata. 2006. Credit Management Handbook. Jakarta : PT. Raja Grafindo Persada.

Sartono, Agus. 2000. Manajemen Keuangan. Yogyakarta : BPFE.

Siagian, Sondang P. 2000. Perencanaan Staf Dalam Manajemen. Jakarta : PT. Gunung Agung.

Sinungan, Muchdarsyah. 2000. Manajemen Dana Bank. Jakarta : PT. Bumi Aksara.

Susilo, Y. Sri. 2002. Bank dan Lembaga Keuangan Lain. Jakarta : Salemba Empat.

Sutojo, Siswanto. 2000. Manajemen Terapan Bank. Jakarta : Pustaka Binaman Pressindo.

Suyatno, Thomas. 2000. Dasar-Dasar Perkreditan. Jakarta : PT. Gramedia Pustaka Utama.

Undang-Undang Perbankan No. 10 Tahun 1998 Tentang Perbankan. 2002. Jakarta : Sinar Grafika.

Weston, J. Fred dan Copeland, Thomas E. 2000. Manajemen Keuangan. Jakarta : Erlangga. 